\title{
The use of pectoralis major flaps during axillary dissection for bulky axillary lymphadenopathy
}

This article was published in the following Dove Press journal:

Open Access Surgery

3 September 2013

Number of times this article has been viewed

\section{Naomi Mohan \\ Savtaj Singh Brar \\ Jason T Rich \\ Frances Wright \\ Kevin Higgins}

Sunnybrook Health Sciences Centre, Toronto, Ontario, Canada
Correspondence: Naomi Mohan Sunnybrook Health Sciences Centre, 2075 Bayview Ave, Toronto,

ON, Canada, M4 N 3M5

Email 8nmohan@gmail.com
Abstract: There are a multitude of flaps and advanced techniques employed in reconstructive surgery during axillary dissections. The pectoralis major flap has proven, in our experience, to be favored as it provides excellent access to level III of the axilla and vessel coverage.

Keywords: lymphadenopathy, free flap, pectoralis major

\section{Introduction}

Axillary lymphadenopathy is a symptom of a severe and potentially life-threatening condition and may be attributed to several conditions; these conditions include autoimmune diseases, lymphoma, granulomatous disease, and regional metastatic disease, as well as chronic or acute infection. ${ }^{1}$ If the etiology of the lymphadenopathy is from a nonhematological malignancy such as melanoma or squamous cell carcinoma, then a therapeutic lymph node dissection may be recommended. The goal of such a procedure is to resect all microscopic and macroscopic disease. ${ }^{2}$ We report our experience with three patients with massive axillary lymphadenopathy; patients underwent a chest wall rotation advancement flap in a deltopectoral configuration, coupled with an elevation of the pectoralis major myocutaneous flap.

\section{Case report}

A 51-year-old gentleman presented in clinic with rapidly progressive axillary lymphadenopathy from a melanoma of unknown primary. Clinically the lymphadenopathy involved the skin, subcutaneous tissues, and multiple axillary nodes. Staging computed tomography (CT) scans of the head, chest, abdomen, and pelvis confirmed no distant metastasis. In the axilla, the CT chest delineated that the mass involved part of the latissimus and subscapularis muscle as well as the axillary vein, but spared the pectoralis major, pectoralis minor, serratus muscles, chest wall, and the axillary artery and brachial plexus. Surgery was highly recommended to the patient in order to control the regional nodal disease.

At initiation of surgery, the incision was marked in a curvilinear fashion in order to afford exposure of the pectoralis major, as well as to allow for the chest wall skin to rotate and advance, based on perforating vessels within the clavicopectoral fascia (see Figure 1). This flap was created in order to provide access to the level III axillary nodes and to provide coverage of the axillary vessels, as well as obliterate dead space.

The chest wall advancement flap was then elevated deep to the pectoral fascia, respecting the second and third rib interspaces, in order to facilitate preservation 


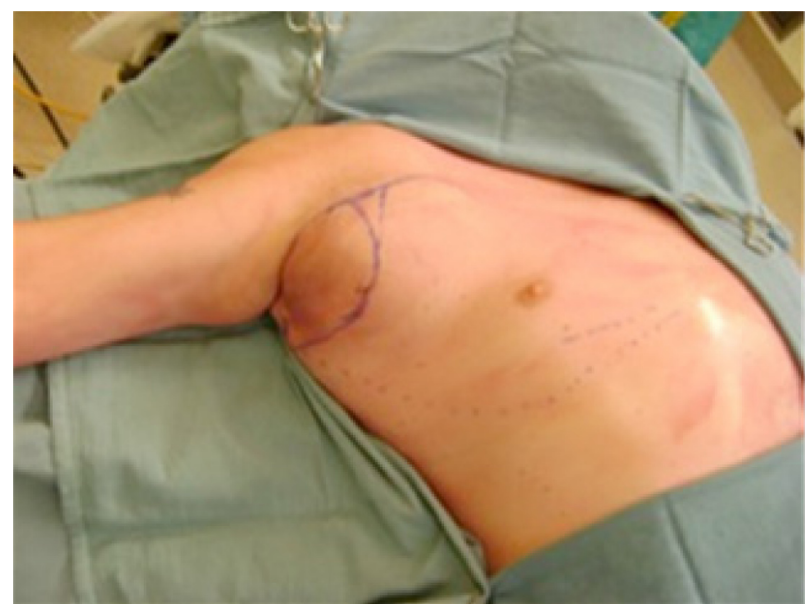

Figure I Preoperative curvilinear marking.

of the dominant perforators from the internal mammary. The pectoralis major was then separated from the serratus anterior and the pectoralis minor (see Figure 2). The lateral thoracic and pectoral branch of the thoracoacromial vessels remained intact and preserved.

The intercostal attachments from the second and ninth ribs were taken down sharply with monopolar cautery, and the intercostal perforators were controlled with vessel clips. Following this, the GIA stapler (Covidien PLC, Mansfield, MA, USA) was used to release the sternal attachments, preserving a $2 \mathrm{~cm}$ cuff muscle along the sternal border and protecting the clavicopectoral flap perforators. The humeral attachment was taken down with the GIA stapler towards the deltopectoral groove, to level with the cephalic vein. Medial and lateral pectoral nerves were then divided to allow atrophy, obliterating the dead space in the axilla and affording coverage of the axillary vessels and brachial plexus (see Figure 3). The chest wall flap easily adapted to

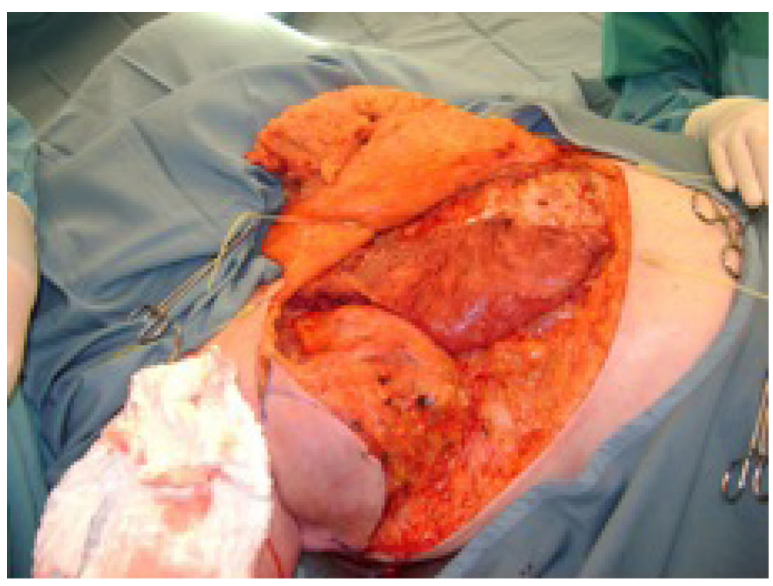

Figure 2 Chest wall advancement flap.

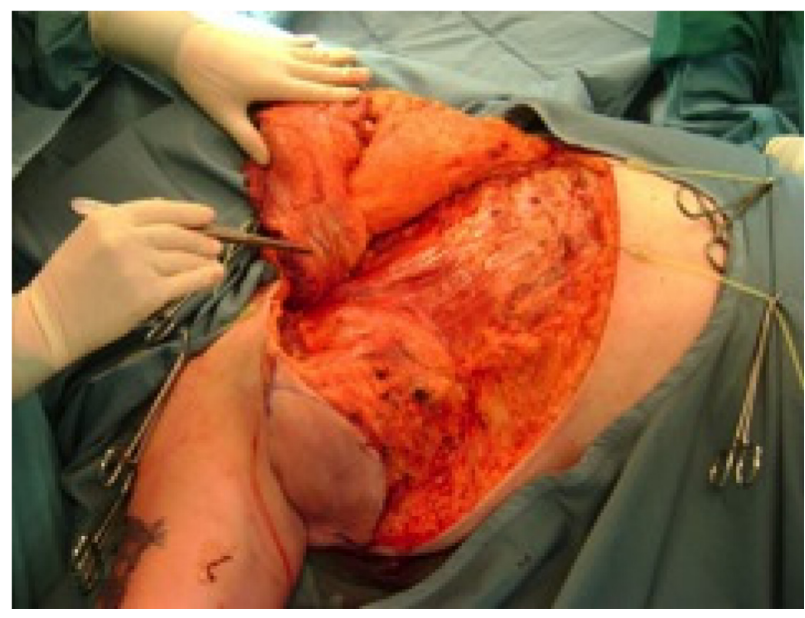

Figure 3 Pectoralis major flap.

the cutaneous defect. There were no complications related to the reconstructive portion of the procedure.

Once the myocutaneous flap was elevated, the mass was clearly visible. The mass was then resected off the chest wall, preserving the long thoracic nerve. Two sections of the latissimus and subscapularis muscles were removed during the case due to involvement. The level III contents were dissected en bloc, and the axillary vein was identified and confirmed to be directly encased by the tumor. A significant collateral venous plexus was recognized, the axillary vein was ligated, and finally, the $15 \mathrm{~cm}$ mass was resected. The flap was then replaced, and the pectoralis major was positioned on top of the vessels.

Two comparable cases are presented, in which an analogous technique was used (See Table 1). For all three cases outlined here, each patient presented for axillary clearance at an advanced stage of disease, with axillary defects. Therefore, it follows that each surgery was, to an extent, quite precarious, with a sophisticated level of difficulty. In each of the three cases, the pectoralis major flap served as an excellent method for reconstruction. The flaps were monitored routinely, with no issues in the postoperative recovery of the flaps; each atrophied well, with excellent final contour and volume restoration.

\section{Discussion}

The three cases presented illustrate the benefits of the pectoralis major flap in the level I, II, and III axillary dissection for massive axillary lymphadenopathy. Importantly, the flap facilitates access to the level III nodes, which enables proximal and distal control of the subclavian and axillary vessels during resection. After the resection is completed, the flap provides excellent vessel protection, and eliminates 
Table I Clinical characteristics of three cases employing pectoralis major flap

\begin{tabular}{|c|c|c|c|c|c|c|}
\hline $\begin{array}{l}\text { Case } \\
\text { designation }\end{array}$ & Age & Sex & Pathology & Surgery & $\begin{array}{l}\text { Use of pectoralis } \\
\text { major flap }\end{array}$ & $\begin{array}{l}\text { Postoperative } \\
\text { results }\end{array}$ \\
\hline I & 51 & Male & $\begin{array}{l}\text { Melanoma involving a } 15 \mathrm{~cm} \\
\text { axillary mass. Rapidly progressive } \\
\text { regional metastasis involving } \\
\text { latissimus and subscapularis muscle, } \\
\text { axillary vein, and skin. }\end{array}$ & $\begin{array}{l}\text { Chest wall advancement } \\
\text { flap, mass dissected at its } \\
\text { lower aspect and long } \\
\text { thoracic nerve preserved. } \\
\text { Level I, II, and III axillary } \\
\text { dissection. }\end{array}$ & $\begin{array}{l}\text { Afford coverage of axillary } \\
\text { vessels and brachial } \\
\text { plexus, as well as eradicate } \\
\text { dead space in the axilla. }\end{array}$ & Uneventful \\
\hline 2 & 81 & Male & $\begin{array}{l}\text { Squamous cell carcinoma in } \\
\text { right axillary lymph nodes and } \\
\text { demonstration of dermal } \\
\text { infiltration. Axillary mass } \\
7 \times 9.5 \times 4 \mathrm{~cm} \text { in size. }\end{array}$ & $\begin{array}{l}\text { Chest wall rotation } \\
\text { advancement flap. Level I, II, } \\
\text { and III axillary dissection. }\end{array}$ & $\begin{array}{l}\text { Complete axillary vein } \\
\text { coverage, wide exposure } \\
\text { of level III of the axilla. } \\
\text { Obliterate dead space } \\
\text { in ablative defect. }\end{array}$ & $\begin{array}{l}\text { Postoperative } \\
\text { radiation, } \\
\text { no issues in } \\
\text { recovery of flap. }\end{array}$ \\
\hline 3 & 66 & Male & $\begin{array}{l}\text { Metastatic malignant melanoma } \\
\text { deposit with subcutaneous } \\
\text { infiltration. Axillary adenopathy } \\
\text { involving levels II and III. Eleven } \\
\text { positive lymph nodes, ranging } \\
\text { from } 0.5 \text { to } 5.3 \mathrm{~cm} \text {. }\end{array}$ & $\begin{array}{l}\text { Elevation of large chest wall } \\
\text { flap. Level I, II and III axillary } \\
\text { dissection. }\end{array}$ & $\begin{array}{l}\text { Coverage of dissected } \\
\text { axillary artery and vein. }\end{array}$ & $\begin{array}{l}\text { Postoperative } \\
\text { radiation, } \\
\text { no issues in } \\
\text { recovery of flap. }\end{array}$ \\
\hline
\end{tabular}

dead space. ${ }^{3}$ Other advantages of the pectoralis major flap include its rich vascularity, large skin territory, improved arc of rotation, ability to transfer without prior delay, increased bulk, ease of harvest in the supine position, and primary donor site closure. ${ }^{4}$

Patients undertaking this radical surgery, however, are at risk for several surgical complications, including brachial plexus injury, chylous fistula, great vessel injury, spinalaccessory injury, and accessory neuropathy. Furthermore, postoperative treatment, such as chemotherapy and radiation, are likely to be necessary, as observed in two of the cases displayed in Table 1. Neuropathic pain, numbness, swelling, infection, and reduced mobility in the upper arm and chest region are all significant consequences resulting from axillary dissection for bulky lymphadenopathy. Lymphedema is also a major concern upon undergoing such invasive surgery; careful control must therefore be taken in order to prevent injury to lymphatic vessels, which might result in such a condition. ${ }^{4}$ Additional caution must be taken when employing pectoralis major flaps in order to avoid such complications, which are attributable to the large bulk of the flaps. Pectoralis major flaps have proven to be particularly useful as a salvage procedure following ablative surgery, with reduced operative times, costs, and risk of total flap necrosis. ${ }^{5}$ In fact, in a retrospective review of the use of pectoralis major flaps in the treatment of oropharyngeal squamous cell carcinoma, and among cases presenting as either advanced stage 4 primary disease, extensive recurrent, or metastatic neck disease, the pectoralis major flap was the preferred reconstruction method for those patients with particularly advanced disease, with a complete flap failure rate of $2.8 \%{ }^{6}$ Additionally, the pectoralis major flap was proven to play the most pragmatic role in the management of metastatic disease, especially when the method of surgical resection of the disease is aggressive. ${ }^{6}$

\section{Conclusion}

In summary, pectoralis major flaps are both successful and proficient for radical axillary dissection as they provide excellent level III access and vessel coverage in reconstruction, in addition to being in close proximity to the head and neck. They are a superior technique over other flaps in this sense, as they provide an unparalleled level of exposure and protection, as well as efficient elimination of dead space.

\section{Disclosure}

The authors report no conflicts of interest in this work.

\section{References}

1. Morgan RH, Horgan K, Hughes LE. Use of myocutaneous flaps for primary cover following lymph node dissection for malignant melanoma. Br J Surg. 1988;75(1):65-68.

2. Vartanian JG, Carvalho AL, Carvalho SM, Mizobe L, Magrin J, Kowalski LP. Pectoralis major and other myofascial/myocutaneous flaps in head and neck cancer reconstruction: experience with 437 cases at a single institution. Head Neck. 2004;26(12):1018-1023.

3. Ariyan S. The pectoralis major myocutaneous flap. A versatile flap for reconstruction in the head and neck. Plast Reconstr Surg. 1979;63(1): 73-81.

4. Schusterman MA, Kroll SS, Weber RS, Byers RM, Guillamondegui O, Goepfert H. Intraoral soft tissue reconstruction after cancer ablation: a comparison of the pectoralis major flap and the free radial forearm flap. Am J Surg. 1991;162(4):397-399. 
5. Chiummariello S, Iera M, Domatsogiou A, Alfano C. The use of pectoralis major myocutaneous flap as "salvage procedure" following intraoral and oropharyngeal cancer excision. G Chir. 2010;31(4):191-196.
6. Aver CM, Crank ST, Neal CP, Hayter JP, Elton C. The use of pectoralis major flap for advanced and recurrent head and neck malignancy in the medically compromised patient. Oral Oncol. 2010;46(11):829-833.
Open Access Surgery

\section{Publish your work in this journal}

Open Access Surgery is an international, peer-reviewed, open access journal that focuses on all aspects of surgical procedures and interventions. Patient care around the peri-operative period and patient outcomes post surgery are key topics. All grades of surgery from minor cosmetic interventions to major surgical procedures are covered. Novel techniques

Submit your manuscript here: http://www.dovepress.com/open-access-surgery-journal

\section{Dovepress}

and the utilization of new instruments and materials, including implants and prostheses that optimize outcomes constitute major areas of interest. The manuscript management system is completely online and includes a very quick and fair peer-review system. Visit http://www.dovepress.com/ testimonials.php to read real quotes from published authors. 